\title{
Evaluation of Creative (Metal) Industry Development Policy in Dealing with the ASEAN Economic Community in Sidoarjo
}

\author{
Berliana Mustika Rani•
}

\begin{abstract}
Economic Kreatif is one of the progress factors of the national economy. The creative economy concentrates on the economic dynamics of the creative industry sector, which was recently targeted by the government as an area with significant growth potential. On January 20, 2015, President Joko Widodo established a new non-ministerial institution called the Creative Economy Agency (Bekraf). This body is responsible for the expansion of the creative economy in Indonesia. East Java has 29 districts and 9 cities, a number of which host creative industry businesses in the field of SMEs, namely Sidoarjo district. Sidoarjo regency, which is one of the regencies in East Java, is focused on the development of Micro Small Medium Enterprises in facing the ASEAN Economic Community (AEC). The primary creative industry in Sidoarjo district are the Metal Industries in Ngingas Village, Waru Sub-district. The small and medium industry (IKM) metal center of Ngingas, Sidoarjo, East Java is one of the component suppliers for major manufacturing companies in Indonesia. Craftsmen in these industrial centers are constrained by licensing problems. They are also constrained by limited business capital for the procurement of raw materials and production machinery, and the lack of metal waste disposal facilities.
\end{abstract}

Keyword:

creative economy; monitoring; evaluation.

\section{Introduction}

The world economy initially relied on income derived from agricultural products, better known as an agrarian economy or agricultural economy. Over time, the discovery of steam engines, followed by the industrial revolution in the UK and the rapid advancement of information technology, changed this. State revenues no longer needed to come solely from raw materials since there were fewer restrictions on distance and time. From this, the creative economy emerged as a potential source of increased state revenue.

The Ministry of Tourism and Creative Economy, which was formed on October 19, 2011, oversees creative economic development in Indonesia. Creative Economy is an economic activity that relies on the creative power of individuals to fuel economic growth and influence the welfare of society (Inpres No. 6 Year 2009). The creative economy must be nurtured in order to improve the national economy. This is because Indonesia is a country with low Gross Domestic Product (GDP) compared to other ASEAN countries. Based on reports from the World Economic Forum (WEF) in Davos Switzerland, Indonesia is ranked among the world's 42 top countries based on Gross Domestic Product (GDP), along with 15 other ASEAN countries, including Singapore, Thailand, and Malaysia. (Source: economy.okezone.com)

The Creative Economy contributed 852 trillion rupiah, or7.38 percent of the total national economy in 2015 (Source: www.bekraf.go.id). Therefore, can be considered a significant source of national income and must be developed.

\footnotetext{
- Master of Public Policy, Faculty of Social and Political Sciences, Airlangga University.

Email: berliana.rani@gmail.com
} 
Figure 1.

Contribution of GDP of Creative Economy by Subsector

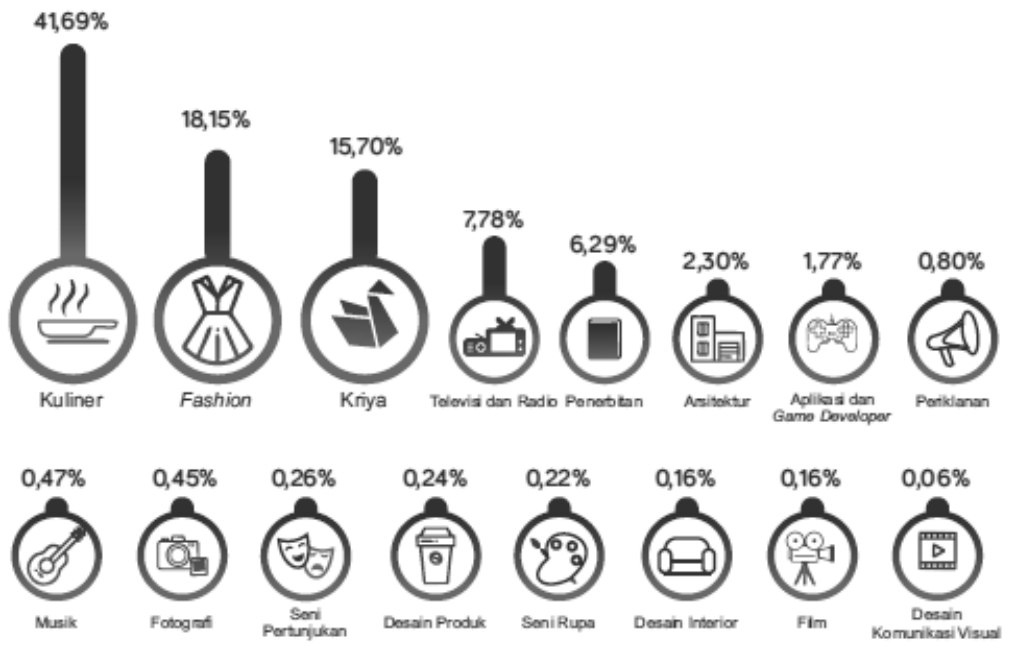

PERTUMBUHAN PESAT 4 SUBSEKTOR

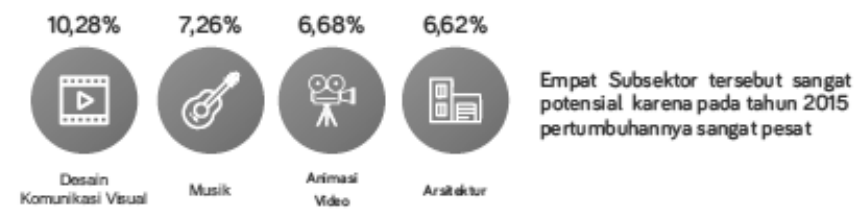

Source: www.bekraf.go.id, 2017

The creative economy concentrates on the economic dynamics of the creative industry sector. The scope of the creative industry covers 16 architectural sub-sectors (industry): interior design; visual communication design; product design; fashion; movies, animations and videos; photography; crafts; culinary; music; application and game development; publishing; advertising; performing arts; and fine arts, as well as television and radio. (Presidential Regulation No. 72 of 2015). The development of creative industries by the government is not without reason because the creative industry creates jobs and involves many elements of the nation's cultural values so as to boost national pride.

On January 20, 2015, President Joko Widodo established a new non-ministerial institution called the Creative Economy Agency (Bekraf). This body is responsible for the development of the creative economy in Indonesia. Bekraf is in charge of assisting the president in formulating, defining, coordinating, and synchronizing government policies. Bekraf has excellent programs that are classified into six Deputies, namely:

1. The Superior Program of Deputy I The Deputy for Research, Education, and Development designs several programs related to research and learning to strengthen the foundations of the creative economy.

2. Superior Program of Deputy II Creative Economy Fund (DEKRAF).

3. Superior Program of Deputy III Infrastructure development, which is the foundation for the creation of a creative economic ecosystem, allows actors to interact, work together, and share ideas.

4. Superior Program of Deputy IV The Deputy of Marketing prepares promotional and branding programs for 
the products and services of the national creative industry, both in the domestic and global markets.

5. Deputy Superior Program V

Intellectual property is the fundamental force of the creative economy. The Deputy of IPR Facilitation and Regulation prepare programs related to IPR protection.

6. Superior Program of Deputy VI

The Deputy Relations Programs between Institutions and Territories allow Bekraf and creative economy actors to work together in institutions and organizations. (Source: www.bekraf.go.id)

These programs combined make up the government's efforts to deal with the ASEAN Economic Community (AEC), adopted in December 2015. Indonesia's preparedness in dealing with the ASEAN Economic Community (AEC) is still lacking and much needs to be improved in terms of human resources, supporting facilities, and infrastructure, as well as the mindset of the Indonesian people. The Regional Government also plays an important role in the readiness of Indonesia to face the ASEAN Free Market.
The national industry is still not considered ready to face the ASEAN Economic Community (AEC), which will be enacted in December 2015. There are many challenges that must be faced to make the domestic industry competitive when the ASEAN free market is enacted. Minister of Industry MS Hidayat explained that a number of challenges still face the national industry. This includes the provincial minimum wage increase (UMP), which is not proportional to the increase in labor productivity. Other areas of concern include the lack of gas supply for the manufacturing industry, the burden of electricity tariffs to support the industry downstream, and limited access to business credit (KUR). In addition, more foreign investment in the primary sector, low quality of human resources (HR) in the industrial sector, poor use of fiscal incentives, and a proliferation of illegal imports in the domestic market hinder growth. Other challenges facing the national industry are the lack of cooperation between industry sectors, lack of quality control for imports, and a lack of regulations to protect domestic industries from unfair trade practices. (Source: www. kemenperin.go.id)

Figure 2.

\section{Constraints Faced by Business/Corporate Creative Economy}

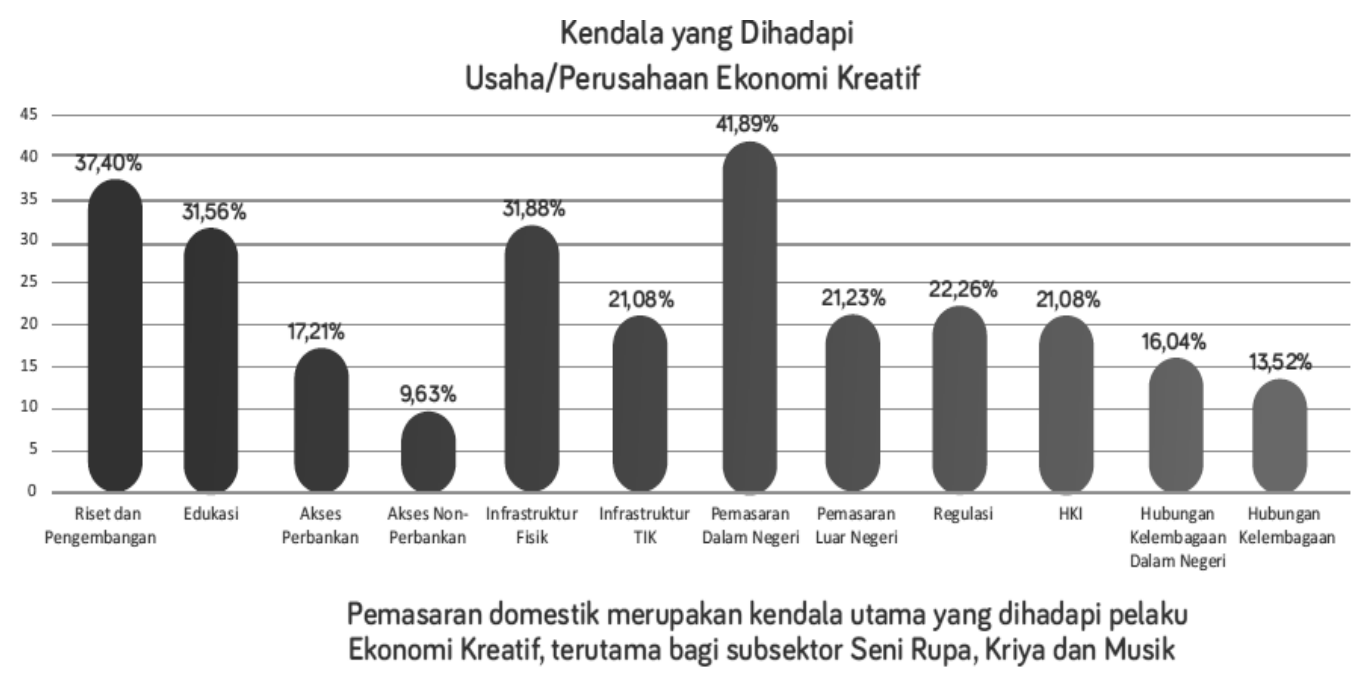

Source: wwww.bekraf.go.id, 2017 
The Village Minister of Disadvantaged Areas Development and Transmigration (Village Minister of PDTT), Marwan Jafar, stressed the importance of strengthening the village-based SMEs (Micro, Small and Medium Enterprises). This requires a special strategy to strengthen Micro Small Medium Enterprises in villages before facing the AEC in 2015. The strategy, Marwan continued, includes increasing the insight that village SMEs have about AEC, especially the very basics. This includes anything related to the prospects and challenges in the AEC. This needs to be done because of the currently limited knowledge within the community and small micro medium business actors about AEC (Source: kompas.com).

East Java Province is home to the largest concentration of creative industry businesses in Indonesia. The ASEAN Economic Community (AEC) prioritizes the development of creative industries through various aspects of the production system, technology, and credit granting. So, it is expected to help in improving its competitiveness so that it is not inferior to the other ASEAN countries. East Java is a province in a position to increase exports of these products and services to various countries. The creative economy needs to be developed because of its potential to contribute more to the progress of the national economy.

Basically, East Java Province is ready to implement the strategies of AEC 2015. This was spurred by the global trade issues that emerged ten years ago. One policy focus of the East Java Provincial Government, in this case, is increasing product competitiveness and consumer protection by using Indonesian National Standard (SNI). The East Java Provincial Government continues to encourage the use of UMKM products by domestic consumers. Currently purchasing trends show that consumers want a cheap product, but also demand good quality. Therefore, all technical institutions, such as UMKM Builders, shall facilitate UMKM in requiring the standardization of goods and services for free as mandated by Law No. 20 of 2014 on Standardization and Conformity Assessment. The East Java Provincial Government has two important policies that will increase the export of goods and services that will enter East Java and goods and services produced by UMKM. In addition, the resulting product can be fulfilled by Security, Health, Safety, and Environment (K3L). This is intended to

Figure 3.

\section{Export of Creative Economy from Each Province}
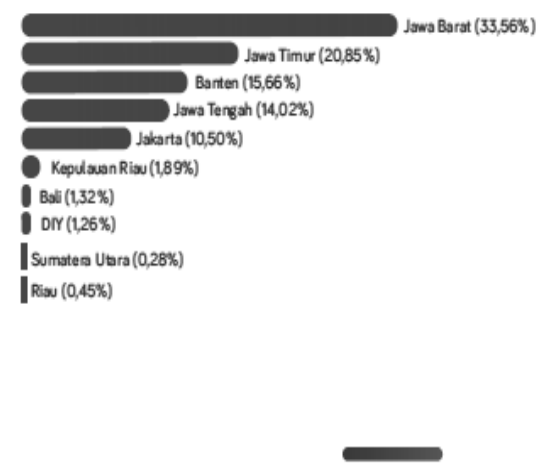

Source: wwww.bekraf.go.id, 2017

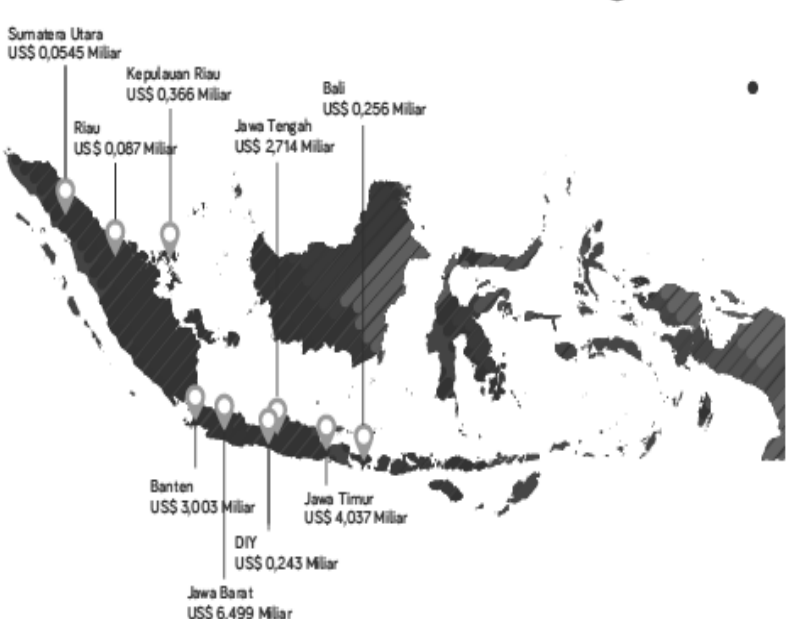

USS 6,499 Mition 
improve the competitiveness of the products produced and expand the acceptability of the product (source: www.bsn.go.id).

East Java has 29 districts and 9 cities, including a number of regencies and cities that host many creative industries in the field of UMKM, namely Sidoarjo district. Sidoarjo regency in East Java also focuses on the development of Micro Small Medium Enterprises to be competitive within the ASEAN Economic Community (AEC).

Sidoarjo regency covers 591.59 square kilometers divided into 18 sub-districts and there are 171,264 business areas. Of these, 16,000 are categorized as large businesses, 154,891 are micro enterprises, and 154 are considered small-scale businesses. In addition, there are still 82 industrial centers growing and the area has added about 11 business villages (kampong batik, snack hamlet, duck village, kampong krupuk, kampong shoe, kampung sayangan, kampong lele, mushroom kampong, kampong smoked fish and many other kampung) (Source: surabayanewsweek.com).

The primary creative industry in Sidoarjo district is the Metal Industry in Ngingas Village, Waru Sub-district. The IKM metal center of Ngingas, Sidoarjo, East Java is one of the component suppliers for major manufacturing companies in Indonesia. Various excellent products are produced, such as agricultural machinery, household appliances, electrical and tecnology components, and automobile parts. “In Ngingas metal center there are about 300 business units. The existence of centers that have existed since the 1930s continues to contribute a very meaningful in improving the welfare of the community. It is also able to encourage the progress of domestic industry," said Minister of Industry Airlangga Hartarto when visiting the center of IKM metal Ngingas, Sidoarjo, East Java, Monday (27/2) (Source: www.kemenperin.go.id).

The metal industry still faces many obstacles to the implementation of its production. Though the industry is said to have great influence on the economy in Sidoarjo because it provides many jobs. Constraints faced include the problem of licensing, access to raw materials, production machinery, the registration of Industrial Registry (TDI), the establishment of Building Permits (IMB), waste disposal, and many more.

Craftsmen in the industrial centers of metal crafts Ngingas Village, District Waru, Sidoarjo regency, East Java, are constrained by licensing restrictions. They are also constrained by limited business capital for the procurement of raw materials and production machinery. In fact, crafters want to grow and be competitive in the era of free trade. Craftsmen in Ngingas are mostly home-based businesses. Production work blends with the home environment. The space for business is very limited because it is in the middle of dense settlements. Another problem is the maintenance of Industrial Registry (TDI) which requires a building permit (IMB). To get the IMB, businesses must first obtain the permit of environmental disturbance (HO). Environmental management issues are another concern. According to Agus, there should be special regulations for MSMEs to manage licensing. For example, free $\mathrm{HO}$ in order to get IMB. In addition, in relation to environmental management, the government should support the construction of communal waste dumps (Source: www.pressreader.com, Kompas).

Constraints experienced by the metal industry craftsmen show that the programs that have been implemented by the need to be evaluated. Oversight becomes very important in the public policy process to monitor the extent of the impact of the policy. Evaluation is a way to measure the achievement of goals and targets set in public policy making. Thus, the policy can be deemed a success or failure.

Thomas Dye states that policy evaluation is an objective, systematic, and empirical examination of the effects of public policies and programs on the target in terms of the 
objectives to be achieved. (Dye in Parson, 2005: 347). Meanwhile, according to Lester and Steward, evaluation can be differentiated into two different tasks. First, determine what consequences a policy creates by describing it. Second, assess the success or failure of a policy based on predefined standards or criteria (Lester and Steward in Winarno, 2008: 226).

According to Patton and Sawicki (1986: 311-321), there are six basic approaches to the evaluation of policies or programs, as follows:

1. Comparison of pre-and post-implementation policies or programs (before-and-after comparisons). The assumption of this approach is that any change that occurs after the policy or program is implemented can be attributed to that policy or program.

2. Comparison between with-and-without policies or programs (with-and-without comparisons). This approach is a modification of the first approach that includes a comparison of relevant criteria on-site with the program compared to data collected before the program was implemented.

3. Comparison between real results and planned performance (Actual-versusPlanned Performance Comparisons). This approach compares actual post-program data to targets that are defined before the program is implemented. Evaluators set specific objectives and targets as evaluation criteria for specific time periods, then collect data on actual performance. Finally, evaluators compare actual performance with performance targets, and try to determine the reason for the differences caused by program and non-program factors.

4. Experimental or Controlled Model (Experimental or Controlled Model).

5. Semi-experimental Model (QuasiExperimental Models). This model is particularly useful if the actual experiment cannot be implemented, either because it cannot select participants for the treatment and control group, cannot control the administration of the program or policy, because of policy restrictions on the treatment group, or because the program is not directed at the individual level.

6. Cost-oriented evaluation approach

The evaluation of a public policy or program, according to Patton and Sawicki, requires a basic approach that compares the actual results with the planned performance. In this case, the role of evaluator is very important in determining the success of the policy evaluation process or program. One of the most important is the human resources (HR) apparatus. Thus, qualified personnel determine the success of a policy. Fitz-enz (2009: 78-90) in his book "ROI of Human Capital: Measuring the Economic Value of Employee Performance", says that the role of human resources in achieving the expected outcomes is crucial. Some of the most successful member nations - such as Malaysia, the Philippines and Singapore-have developed a framework by devising a specific Code of Conduct based on professionalism, productivity, responsibility, and leadership values, and creating a Culture of Excellence.

From the explanation, it is important to note the "Evaluation of Creative Industry Development Policy in Dealing the ASEAN Economic Community (AEC) in Sidoarjo".

\section{Creative Industry \\ Understanding Creative Industries}

There are several definitions of creative industries proposed by various experts, namely as follows: The definition of creative industries according to the United Kingdom, the Department of Culture, Media, and Sports (UK DCMS) that formed the Creative Industry Task Force in the Department of Commerce (2008: 4) states, "The Creative Industry as an industry derived from individual creativity, skill and talent, and has the potential for 
wealth and employment creation through the generation and exploitation of intellectual property and content". The Ministry of Trade of the Republic of Indonesia (2008:4) uses these references, so in Indonesia the creative industries are as follows: "Industries derived from the utilization of creativity, skills, and talents of individuals to create prosperity as well as the creation and utilization of the creative and creative power of the individual". In addition to the above opinion, Simatupang (2007) is an industry that relies on the creation and exploitation of creative works such as art, film, games, or fashion design and includes intercultural creative services such as advertising. John Howkins, in his book "The Creative Economy How People Generate Money of Ideas", explained that economically is an economic activity derived from input and output in the form of ideas (Afiff, 2012).

\section{Productive space of the creative industries}

The scope of creative industries includes 16 sub-sectors: (industrial) architecture; interior design; visual communication design; product design; mode; movies, animations and videos; photography; crafts; culinary; music; apps and game developers; broadcast, performances, fine arts, and television. (Presidential Regulation No. 72 of 2015)

\section{Actors and Drivers Factors Creative Industries}

The actors who are the driving force of the creative industries are (Ministry of Commerce, 2008: 54 - 57):

1. Scholar - The scholar is someone who possesses expertise and skill in the arts and sciences. This creative industry sector consists of researchers, writers, actors, culturalists, artists, teachers, and other figures in the arts, culture, and sciences related to the creative industry.

2. Business - The business is an organizational unit formed to produce goods and services. This business is usually owned by private parties and its purpose is to generate profits for the company and improve community welfare.

3. Government - The government is an organization that has the authority of the State. The role government is to oversee facets of development associated with monopolies, externalities, public goods, asymmetric information, high inefficiencies, and inequality of development outcomes.

Figure 4.

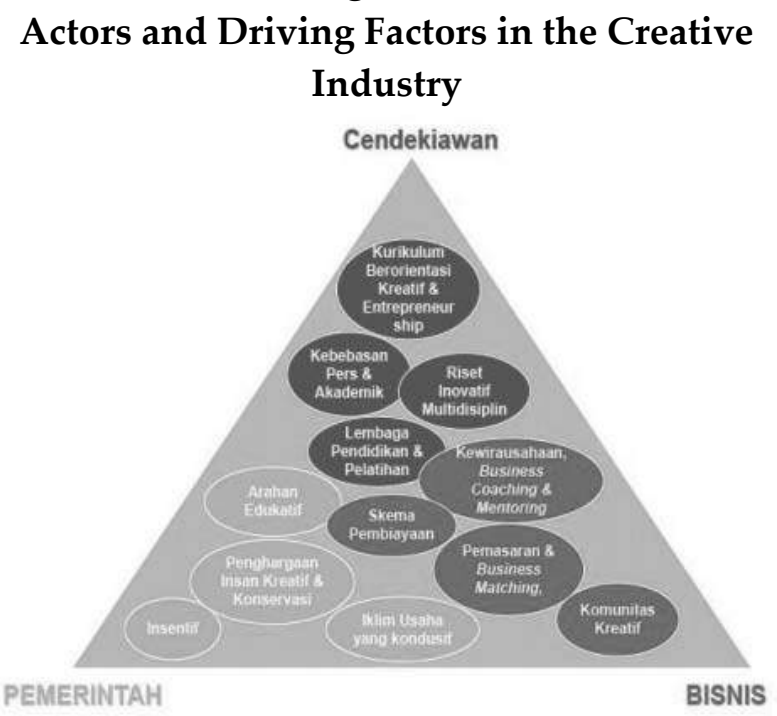

Source: Departemen Perdagangan RI, 2008

\section{Public Policy Evaluation \\ Definition}

Worthen and Sanders (1981:19) provide a definition of evaluation. "Evaluation is the determination of the worth of a thing. It includes obtaining information for use in judging in the worth of a program, product, procedure, or objective or the potential utility of alternative approaches, designed to attain specified objectives." Evaluation is the determination of the value of an object. Ift is used to obtain information to help assess the value of the program, product, procedure, purpose, or potential utility of alternative approaches. In addition, according to Kaufman and Thomas (1980: 4), "evaluation is a process used to assess 
the quality of what is going on." Which means that Evaluation is the process used to assess the quality of the policy.

According to Lester and Stewart (Winarno, 2008: 166), policy evaluation can be differentiated into two different tasks. The first task is to determine the consequences of a policy by describing its impact. The second task is to assess the success or failure of a policy based on predefined standards or criteria. Evaluation of the policy is a matter of fact in the form of measurement and assessment of both the implementation phase of the policy and the outcome or impact of the operation of a certain policy or program. This will determine the steps that can be taken in the future.

\section{Purpose}

According to Edi Suharto (2012: 61), the goal of public social policy, in the context of social development, is to serve as a tool, mechanism, and system that can direct and translate development goals. Social policy is always oriented towards the achievement of social goals. This social goal contains two interrelated understandings, namely solving social problems and meeting social needs.

According to Suharsimi (2004: 13), there are two kinds of evaluation objectives. Namely, general goals and special goals. General goals are directed at the program as a whole, while the specific objectives are directed at each component. Program evaluators are required to be able to recognize the components of the program.

\section{Types of Policy Evaluation}

James Anderson, in Winarno (2008: 229), divides the policy evaluation into three types. Each type of evaluation is based on the evaluator's understanding of the evaluation, as follows:

1. The first type: The policy evaluation is understood as a functional activity. When a policy evaluation is understood as a functional activity, it becomes as important as the policy itself.

2. The second type: This is an evaluation type that focuses on the workings of certain policies or programs. This type of evaluation is focuses on judging honesty and efficiency in implementing the program.

3. The third type: The final systematic policy evaluation type looks objectively at the policy and programs to measure the impact on the community and see how well the stated objectives have been achieved.

\section{Evaluation Model Policy}

There are eight evaluation models, according to Kaufman and Thomas in Suharsimi (2010: 40), namely:

1. Goal-Oriented Evaluation Model, developed by Tyler. This model is the earliest. The object of this model is to evaluate in terms of a set of goals that are pre-defined long before the program begins.

2. Goal-Free Evaluation Model, developed by Scriven. This model can be said to be contrary to the first model developed by Tyler. This external evaluation model monitors the process and results with no former knowledge of the intended goal.

3. Formative Summative Evaluation Model, developed by Michael Scriven. This model shows the stages and the scope of the object being evaluated, i.e. the evaluation process encompasses the entire run of the program and is only completed (formative evaluation) when the program is completed (summative evaluation).

4. Countenance Evaluation Model, developed by Stake. This model emphasizes the existence of two main things, namely (1) description and (2) consideration.

5. CSE - UCLA Evaluation Model, emphasizes on "when" evaluation is done. This model has five stages: planning, development, implementation, results, and impact. 
6. CIPP Evaluation Model, developed by Stufflebeam. This model is the model most widely known and applied by the evaluators. The CIPP model is an evaluation model that views programs as a system and bases the evaluation on an analysis of its components.

7. Discrepancy Model, developed by Provus. This model emphasizes the view of gaps in program implementation. Evaluation of the program is to measure the magnitude of the gap in each component.

8. Discrepancies Evaluation Model (DEM), by Provus. This model focuses on benchmarking the evaluation results with predefined performance standards. Evaluation results are used for policymaking on programs that have been implemented to determine whether they will be increased, will be continued, or will be discontinued. Provus says evaluation is the process of (a) agreeing upon a standard program, (b) determining whether a discrepancy exists between some aspects of the program, and (c) using discrepancies information to identify the weaknesses of the program.

In this context, the author will use the evaluation model developed by Stufflebeam et al (1967) at Ohio State University, the CIPP Evaluation Model. CIPP is an acronym taken from:

1. Context Evaluation, or evaluation of context

2. Input Evaluation, or evaluation of inputs

3. Process Evaluation, or evaluation of process

4. Product Evaluation, or evaluation of results

\section{CIPP Evaluation Model}

According to Stufflebeam (2003: 2), the CIPP evaluation model (Context, Input, Processes, and Products) is described as follows:

"The model's core concepts are denoted by acronym CIPP, which stands for evaluations of an entity's context, inputs, processes, and products. Context evaluations assess needs, problems, assets, and opportunities to help decisionmakers define goals and priorities and help a broader group of users judge goals, priorities, and outcomes. Input evaluations assess alternative approaches, competing action plans, and budgets for their feasibility and potential cost-effectiveness to meet targeted needs and achieved goals. Decision makers use input evaluations in choosing between competing plans, writing funding proposals, allocation resources, assigning staff, scheduling work, and ultimately in helping others judge an effort's plans and budget."

The core of this CIPP evaluation model consists of four dimensions of evaluation, namely:

1. Context Evaluation (Context)

The context evaluation provides data on the reasons for setting and prioritizing program objectives. This evaluation explains the relevant environmental conditions, describes existing and desirable conditions, and identifies environmental needs.

2. Input Evaluation (Input)

Input evaluation provides data to determine how the use of resources can be used to achieve program objectives. This is related to relevance, practicality, financing (funding), desired effectiveness, and determines alternatives that are considered superior.

3. Process Evaluation (Process)

This step in the evaluation process provides feedback regarding the efficiency of program implementation, including system influence and implementation. This evaluation detects or predicts shortcomings (constraints) in the design of procedures and program implementation.

4. Product Evaluation (Results)

Product evaluation measures and interprets program achievements during program 
implementation and at the end of the program, when measurable results can be analyzed.

(Sudjana, 2006: 54-57)

\section{Approach}

According to Patton and Sawicki (1986: 311-321), there are six basic approaches to the evaluation of policies or programs, as follows: 1. Comparison of pre-and post-implementation policies or programs (before-and-after comparisons): The assumption of this approach is that any discrepancy between data before and after the policy or program is implemented is an outcome of the policy or program.

2. Comparison between with-and-without policies or programs (with and without comparisons): This approach is a modification of the first approach that includes a comparison of relevant criteria on site with the program compared to the location before the program was implemented.

3. Comparison between real results and planned performance (Actual-versusPlanned Performance Comparisons): This approach compares actual post-program data to pre-defined targets. Evaluators set specific objectives as evaluation criteria for specific time periods, then collect data on actual performance. Finally, evaluators compare actual performance with performance targets and try to find the right explanation for the differences caused by program and non-program factors.

4. Experimental or Controlled Model (Experimental or Controlled Model).

5. Semi-experimental model (QuasiExperimental Models): This model is particularly useful if the actual experiment cannot be implemented, either because it cannot select people for the treatment and control group, cannot control the administration of the program or policy, because of policy restrictions on the treatment group, or because the program is not directed at the individual level.

6. Cost-oriented evaluation approach (CostOriented Evaluation Approach): This approach attempts to assess policies or programs by comparing costs for input resources with certain criteria.

According to Stufflebeam and Webster (1994), Dunn (1999), in Mutrofin (2005: 107), classifies the approach and orientation of evaluation research into three groups. These approaches are:

\section{Pseudo-Evaluation}

An approach that uses descriptive methods to generate valid and reliable information on policy outcomes, without seeking to ask about the value of the outcome to the individual, group, or society as a whole. The assumption is that the measure of value will be self-evident. This evaluation specifically implements a variety of methods (quasi-experimental design, questionnaires, random sampling, statistic techniques) to explain variations of existing policy outcomes (e.g. number of hired training graduates, units of medical services provided, net benefits generated).

\section{Formal Evaluation}

An approach that uses descriptive methods to generate valid and reliable information about policy outcomes, but evaluates those results on the basis of policy program objectives that have been formally announced by policymakers and program administrators. The assumption is that objectives and targets that are formally announced are an appropriate measure of the program's value. Formal evaluations are conducted using a variety of methods, such as those used in pseudo-evaluations. Their objective is to produce valid and reliable information about 
policy variations and track the impact of policy inputs and processes. Formal evaluations use laws, program documents, and interviews with policymakers and administrators to identify, define, and specialize policy objectives and targets. The eligibility or accuracy of the formally announced objectives and targets is not in question. In formal evaluations the most commonly used criteria are efficacy and efficiency.

One type of formal evaluation is a summative evaluation that includes businesses that monitor the achievement of formal objectives and targets after a policy or program has been in place for a certain period of time. Alternately, formative evaluation includes efforts to continually monitor the achievement of formal objectives and targets.

3. Theoretical Decision Theoretical Evaluation An approach that uses descriptive methods to generate valid and accountable information about policy outcomes explicitly assessed by various policy actors. The evaluation of theoretical decisions seeks to elicit and make explicit the goals and targets of policy actors, whether hidden or declared. This means that the goals and targets of policymakers and administrators are of utmost importance. All those who have a stake in formulating and implementing policies (for example mid-level and subordinate staff, employees of other bodies, client groups) are involved in formulating the goals and targets upon which performance will be measured.

\section{Discussion}

The creative economy in Indonesia, especially in the creative industry, experienced significant peningakatan so that a big enough impact on the national economy. In 2015, the creative economy contributed 852 trillion rupiah, or 7.38 percent of the total national economy. Program NAWACITA 2015-2019 Item 6 is improving people's productivity and competitive edge in international markets so that the nation of Indonesia can advance and rise with other Asian nations. This lead to a priority sub-agenda to accelerate national economic growth, especially in the creative economy. Strategies to support this include market expansion (export and domestic), facilitation of the process (creative space and creative network), facilitation of creative economic value chains, and start-up facilitation.

The development of the creative economy is also supported by the existence of a body that exists to bolster its development, namely the Creative Economy Agency (Bekraf). Bekraf has excellent programs classified in six Deputies, namely:

1. The Superior Program of Deputy I

The Deputy for Research, Education, and Development designs several programs related to research and learning to strengthen the foundations of the creative economy.

2. Superior Program of Deputy II Creative Economy Fund (DEKRAF).

3. Superior Program of Deputy III Infrastructure development is the foundation for the creation of a creative economic ecosystem, allowing actors to interact, work together, and share ideas.

4. Superior Program of Deputy IV

The Deputy of Marketing prepares promotional and branding programs for the products and services of the national creative industry, either in the domestic or global market.

5. Deputy Superior Program V

Intellectual property is the fundamental force of the creative economy. The Deputy of IPR Facilitation and Regulation prepares programs related to IPR protection.

6. Superior Program of Deputy VI Deputy Relations Programs between Institutions and Territories allow Bekraf and creative economy actors to work together in institutions and organizations. (Source: www.bekraf.go.id) 
Other supporting policies related to the development of the creative economy in Indonesia include:

1. Law No. 20 Year 2008 concerning UMKM

2. Law No. 33 Year 2009 on Film - Encouraging Film Industry Development

3. Law No. 3 of 2014 on Industry - Encouraging the Development of National Creative Industries

4. Law No. 28 of 2014 on Copyright - Providing Intellectual Property Protection for Creative Works

5. Law No. 7 of 2014 on Trade - Encouraging the Trade of Creative Economy-Based Products

Creative economy, or the creative industry in Indonesia is experiencing very rapid growth but its growth is not evenly distributed in all regions. Since the ASEAN Economic Community (AEC) was established in December 2015, creative industries in many regions in Indonesia actually suffered due to an increase in imports. The existence of ACFTA, coupled with the existence of the AEC, worsened the situation. In Sidoarjo, which is famous for its creative industry in the AEC sector, there are some AEC that have declined, for example, the Leather Craft Industry in Tanggulangin. Businesses have found it difficult to compete with foreign products from China, which are cheap but acceptable quality. The buying habits of Indonesians, who tend to choose goods with cheap prices regardless of quality, further aggravate the state of AEC. The same thing is also experienced by craftsmen who make sandals and shoes at Wedoro, Waru Sidoarjo. They experienced a decrease in sales and many even folded due to an inability to compete with cheaper imports, despite the fact that their products are better quality.

The existence of the ASEAN Economic Community (AEC) is still a constraint for the industrial metalcrafters Ngingas Village, District Waru, Sidoarjo District, often known as Kampung Metam They are constrained by licensing problems. This is because it is required to obtain a building permit (IMB). The craftsmen often cannot do this because most of the business is done in the narrow area in front of the house. Therefore, it is not possible to obtain the IMB. They also must have the permit of environmental disruption $(\mathrm{HO})$ and this cannot be done because of the absence of metal waste dumps provided by the government. The government should support the construction of communal waste dumps to facilitate this process.

One o the Creative Economy Agency's flagship mandates is that: "Infrastructure development is the foundation of the creation of a creative economic ecosystem, allowing actors to interact, cooperate and share ideas." However, real metal industry craftsmen are still constrained by infrastructure problems, such as the need a metal waste disposal site. Law No. 3 of 2014 on Industry Article 110 provides that the Government and Local Government can provide facilities to accelerate the development of Industry.

The metal creative industry in Sidoarjo is also constrained by the problem of facilities licensing. How can the industry can grow rapidly if simple problems are still not resolved? Law No. 20 Year 2008 on AEC Article 12 mandates a simplification of the procedures and types of business licensing with a one-stop integrated service system.

Indonesia's creative industries still have many shortcomings that need to be improved, including human resources, infrastructure, funding, and problems with ineffective evaluators.

Creative industries in several foreign countries have become the focus of government attention. Many in the outside world have made excellent policies for the advancement of their creative economy or creative industries. Among them:

Britain was the first country to propose the concept of regulation of creative industries. 
Former Prime Minister Anthony Blair initiated this idea and established the Creative Industries Task Force in 1997, deeming the creative industry as a significant force and source of future economic growth. In the UK, the creative industry is defined as "an activity derived from individual creativity, skill, and talent and which has potential wealth and employment creation through the generation and exploitation of intellectual property." The release of the Creative Industries Mapping Document in 2001 raised the attention of countries worldwide.

The term creative industry is defined differently among different countries, and some of its variants include creative industries (used in the UK and Japan); cultural industries (used in the United Nations Educational, Scientific and Cultural Organization, France and China); Industrial culture (adopted in South Korea); and cultural and creative industries (used in Taiwan, Germany and Hong Kong). Nonetheless, creative industries are increasingly listed as key industries for development by countries around the world. (Liu and Chiu, 2017: 3)

The proliferation of urban-based creative industries has become a key strategy in tackling the economic (and recently social) downturn that has plagued industrial cities and urban spaces. Attention has been focused on attracting, nurturing, and retaining creative practitioners in cities. From Landry's The Creative City (2002) to Florida the Rise of the Creative Class (2002), experts assert that the role of "creative" as a city savior has become almost ubiquitous. While Florida's work has attracted growing criticism over the 'identikit' solution (Chatterton, 2001; Jayne, 2004, 2005; Montgomery, 2005; Nelson, 2005; Oakley, 2004; Peck, 2005), the benefits of nurturing creativity are largely undeniable, especially in policy circles. The study of industrial behavior and creative business activity - and policy interventions aimed at sustaining their growth-tends to follow the urban script, focusing on certain industrial-environmental characteristics (cheap rents in industrial remains, bohemian "restlessness", trendy consumer spaces - see Hutton, 2006) and the types of entrepreneurial and intercompany behavior (networks, grouping) that appear to occur there or appear to require stimulation (see Barthelt et al., 2004). (Bell and Jayne, 2010: 2)

Based on constraints experienced by the Sidoarjo metal industry, it is clear that the monitoring and evaluation process is still not completely effective. In this case, the authors suggest some models of appropriate approach to be applied in monitoring and evaluation, such as:

1. Analytic Network Process (ANP) The Analytic Network Process (ANP) proposed by Saaty (1996) comes from AHP. Saaty (1980) points out that although the Analytic Hierarchy Process (AHP) can facilitate problem-solving involving many conditions and high levels of complexity, this method cannot take interdependence between different conditions (Bell and Jayne, 2010: 2). In this approach, the evaluator puts more emphasis on the value obtained through the super-matrix result composed of the weight ratio of the priority matrix. Thus, the ANP method is more suitable than the AHP method to evaluate policy separately and also to understand the differences and interdependence between criteria. The problems seen within the metal industry are related to problems in other industries. Thus, evaluators should carry out evaluations of various policies made by the government in terms of meeting the needs of the metal industry, such as the construction of facilities and infrastructure. This, in turn, will provide a model to solving problems in other industries within the creative economy.

2. According to Patton and Sawicki (1986: 311-321), the basic approach in evaluating a policy or program is a comparison between actual and planned performance 
(Actual-versus-Planned Performance Comparisons). This approach compares actual post-program data to pre-defined targets, usually before the program is implemented. Evaluators set specific objectives and targets as evaluation criteria for specific time periods, then collect data on actual performance. Finally, evaluators compare actual performance with performance targets and attempt to explain the differences caused by program and non-program factors.

This is certainly very appropriate if used to evaluate the policies made by the government in developing the metal industry in Sidoarjo. Not long ago, Customs Sidoarjo conducted socialization related to the ease of exporting goods abroad.

Customs Office of Sidoarjo continues to facilitate this for small and medium industry actors. They invite metal industry players in Ngingas Village, Waru Subdistrict, Sidoarjo, to read customs information and learn the procedures for bringing in or sending goods abroad. "Small and Medium Industry (IKM) is greatly simplified," said Sidoarjo's Head of Information Counseling and Information Service Sidoarjo, Niken Lestrie (source: surabaya.tribunnews.com).

There are complaints from small industry actors about the difficulty of importing raw materials. Likewise, when exporting, they claim to be constrained. Until now, the metal industry has not been able to export many goods abroad because it is still unable to compete with products from China.

The Sidoarjo Regency Government has shown support through the granting of revolving credit loans, skill training, and socialization of the licensing cooperative regulation (source: www.pressreader.com, Jawa Pos).

Uneven distribution of revolving funds for the development of creative industry businesses makes it difficult for the creative industry players. In Sidoarjo, the priority is the development of creative industries. There are many complaints from the metal industry Ngingas Sidoarjo about their difficulty in buying raw materials due to lack of funds.

\section{Conclusion}

The metal creative industry in Sidoarjo is still not maximized. This development is hindered by the many obstacles they face, including licensing problems, lack of capital to buy raw materials, and a lack of infrastructure. The lack of supervision is a major concern. Although the program has been implemented, its policies have not been evenly distributed in the division. Implementation of unrealized policies in accordance with pre-determined plans and strategies. The suggestion that can be concluded are first, make a policy that suits the needs of the Creative Industry players. Second, meet the basic infrastructure needs of the Creative Industry, such as landfills. Third, perform once-monthly monitoring after the implementation of the program and fourth surveys in advance to determine who is entitled to the provided grants.

\section{References}

Adila, R. (July 3, 2017). Daftar 60 Negara terbaik dunia, Indonesia peringkat 42 . Retrieved from http://economy.okezone. com/read/2016/01/21/320/1293770/daftar60-negara-terbaik-dunia-indonesiaperingkat-42

Bell, D. \& Jayne M. (2010). The creative countryside: Policy and practice In the UK rural cultural economy. Journal of Rural Studies, 26(3), 209-218. doi:10.1016/j. jrurstud.2010.01.001

Data Statistik dan Hasil Survei Ekonomi Kreatif Kerjasama Badan Ekonomi Kreatif dan Badan Pusat Statistik. (2017). Retrieved July 3, 2017, from https://www.google. $\mathrm{com} / \mathrm{url}$ ? sa $=\mathrm{t} \& \mathrm{rct}=\mathrm{j} \& \mathrm{q}=\&$ esrc $=\mathrm{s} \&$ source $=$ 
web\&cd $=6 \&$ cad $=$ rja \&uact $=8 \&$ ved $=0$ ahU KEwinn9ah-P7UAhUfSY8KHS19B74QF ghGMAU\&url=http $\% 3 \mathrm{~A} \% 2 \mathrm{~F} \% 2 \mathrm{Fwww}$. bekraf.go.id\%2Fdownloadable\%2Fpdf_ file $\% 2$ F 170475 -data-statistik-danhasil-survei-ekonomi-kreatif. pdf \& usg = A F QjCNEQ o 7 J 6 _ XWUsion2nm0KKgpzQU6Q

Faiq, N. (July 10, 2017). Undang pelaku industri logam, bea cukai sosialisasikan prosedur ekspor impor. Retrieved from http:// surabaya.tribunnews.com/2017/03/30/ undang-pelaku-industri-logam-bea-cukaisosialisasikan-prosedur-ekspor-impor

Fitz-enz, J. (2009). The ROI of human capital: Measuring the economic value of employee performance, american management association, second edition. New York.

Industri Nasional Belum Siap Hadapi MEA. 2017. Retrieved July 3, 2017, from http://www. kemenperin.go.id/artikel/8098/IndustriNasional-Belum-Siap-Hadapi-MEA

Kaufman, R. \& Thomas, S. (1980). Evaluation without fear. New York: New view point A Division of Franklin Watts.

Keberhasilan satu tahun memimpin. (2017). Retrieved from https://www. pressreader.com/indonesia/jawapos/20170217/282398399174290

Liu, Y. \& Chiu, Y. (2017). Evaluation of the policy of the creative industry for urban development. Sustainability, 9(6), 1009. doi:10.3390/su9061009.

Mutrofin. (2005). Pengantar metode riset evaluasi (kebijakan, program dan proyek). Yogyakarta: Laksbang Pressindo.

Nik. (July 3, 2017). Perajin logam terkendala izin andalkan tengkulak untuk pengadaan bahan baku. Retrieved from https:// www.pressreader.com/indonesia/ kompas/20161105/281956017347079
Patton, C. V. \& Sawicki, D. (1986). Basic methods of policy analysis and planning. New Jersey: Prentice-Hall.

Primus, J. (July 3, 2017). Demi MEA, mari kuatkan UMKM desa!. Retrieved from http://bisniskeuangan.kompas.com/ read/2015/11/05/182156726/Demi.MEA. Mari.Kuatkan.UMKM.Desa

Sentra IKM Logam Ngingas Pasok Komponen ke Manufaktur Besar. (2017). Retrieved July 3, 2017, from http://www.kemenperin.go.id/ artikel/17185/Sentra-IKM-Logam-NgingasPasok-Komponen-ke-Manufaktur-Besar

Soerabaia Newsweek. (July 3, 2017). Sidoarjo layak menjadi kota UKM Indonesia. Retrieved from http://www. surabayanewsweek.com/2016/10/sidoarjolayak-menjadi-kota-ukm.html

Stufflebeam, D. L. (1983). The CIPP model for evaluation. Evaluation Models, 117-141. doi:10.1007/978-94-009-6675-8_7

Sudjana, D. (2006). Evaluasi program pendidikan luar sekolah. Bandung: PT Remaja Rosdakarya.

Suharsimi, A. (2004). Dasar-dasar evaluasi pendidikan. Jakarta: Bumi Aksara.

Suharsimi, A. (2010). Evaluasi program pendidikan: pedoman teoritis praktis bagi mahasiswa dan praktisi pendidikan, second edition. Jakarta: Bumi Aksara.

Suharto, E. (2012). Analisis kebijakan publik. Bandung: CV. Alfabeta.

Tim MEA, PKS-BSN. (July 3, 2017). Surabaya siap menghadapi MEA 2015. Retrieved from http://www.bsn.go.id/main/berita/ berita_det/6249\#.WWWSCrZLfIU

Winarno, B. (2008). Kebijakan publik: Teori dan proses. Jakarta: PT. Buku Kita.

Worthen, B \& Sander J.R. (1981). Education evaluation: Theory and practice. Ohio: Charles A Jones publishing company Worthington. 